\title{
VALUASI EKONOMI EKOWISATA DENGAN MODEL TRAVEL COST DAN DAMPAKNYA TERHADAP USAHA KECIL PARIWISATA
}

\author{
Purwanto \\ Jurusan Manajemen Universitas W.R. Supratman Surabaya \\ Email: cakpo3r@gmail.com
}

\begin{abstract}
Abstrak
Tujuan penilitian ini adalah untuk mengetahui kontribusi industri kecil pariwisata terhadap pendapatan daerah Banyuwangi dan dampak output dan pengganda pendapatan yang dihasilkan oleh industri kecil pariwisata terhadap pertumbuhan ekonomi. Pendekatan yang digunakan ialah input-output. Hasilnya ialah kontribusi usaha kecil pariwisata 15,2\% dari total pendapatan. Koefisien Input Primer usaha kecil pariwisata efisien, karena bisa menciptakan upah, gaji besar, keuntungan atau surplus perusahaan dan pajak tidak langsung. Hal ini juga bisa menjadi mesin penggerak, terutama untuk kegiatan masyarakat dalam industri kecil untuk meningkatkan pertumbuhan ekonomi Banyuwangi.
\end{abstract}

Kata kunci: Biaya perjalanan, valuasi ekonomi, usaha kecil, input-output model.

\begin{abstract}
The objectives were to know tourism small industry contribution on Banyuwangi regional income and output and income multiplier impact generated by tourism small industries toward economy growth. It used input-output approach. Founded that contribution of tourism small enterprise was $15.2 \%$ of total income. Primary Input Coefficient of torism small enterprise was efficient, because it could create big wages, salary, profit or enterprise surplus and indirect tax. It could also become mover machine, especially to society activities in small industry to increase Banyuwangi economic growth.
\end{abstract}

Keywords: Travel cost, economic valuation, small enterprise, input-output model.

\section{PENDAHULUAN}

Pariwisata internasional pada tahun 2004 mencapai kondisi tertinggi sepanjang sejarah dengan mencapai 763 juta orang dan menghasilkan pengeluaran sebesar US\$ 623 miliar (Kementerian Kebudayaan dan Pariwisata, 2005). Kondisi tersebut meningkat 11\% dari jumlah perjalanan tahun 2003 yang mencapai 690 juta orang dengan jumlah pengeluaran US\$ 524 miliar. Diperkirakan jumlah perjalanan wisata dunia di tahun 2010 akan mencapai 1 miliar orang dan di tahun 2020 akan menembus 1,5 miliar orang per tahun. Peningkatan jumlah perjalanan wisata internasional di tahun 2004 tampaknya akan terulang di tahun 2005, walaupun angka resmi dari UN-WTO belum dikeluarkan (Kementerian Kebudayaan dan Pariwisata, 2006). Namun demikian perjalanan wisata di dunia masih dihadapkan kepada permasalahan-permasalahan besar yang meliputi ancaman terorisme dan penyebaran penyakit mematikan (pandemi) yang melanda dunia akhir-akhir ini. World Travel and Tourism Council (WTTC) yang berkedudukan di London, Inggris, pada tahun 2003 telah menerbitkan suatu dokumen yang menggambarkan arah perubahan hubungan antara para pelaku kepariwisataan. Jumlah perjalanan wisatawan mancanegara (wisman) di Indonesia pada tahun 2004 mengalami pertumbuhan sebesar $19,1 \%$ dibanding tahun 2003. Penerimaan devisa mencapai US\$ 4,798 miliar, meningkat 18,8\% dari penerimaan tahun 2003 sebesar US\$ 4,037 miliar. Berdasarkan catatan sementara dari Biro Pusat Statistik, jumlah wisman ke Indonesia pada tahun 2005 berjumlah 5,007 juta atau mengalami penurunan sebesar $5,90 \%$. Penerimaan devisa diperkirakan mencapai US\$ 4,526 miliar atau mengalami penurunan sebesar $5,66 \%$ dibanding tahun 2004. Namun demikian angka perjalanan wisata di dalam negeri (pariwisata nusantara) tetap menunjukan pertumbuhan yang berarti. Di tahun 2005 diperkirakan terjadi 206,8 juta perjalanan (trips) dengan pelaku sebanyak 109,9 juta orang dan menghasilkan pengeluaran sebesar Rp 86,6 Triliun (Kementerian Kebudayaan \& Pariwisata, 2005). Keseluruhan angka tersebut di atas, mencerminkan 
kemampuan pariwisata dalam meningkatkan pendapatan negara, baik dalam bentuk devisa asing maupun perputaran uang di dalam negeri. Pembangunan di bidang pariwisata nampaknya perlu mendapatkan perhatian serius, termasuk bagaimana menciptakan berbagai kreasi pariwisata termasuk di dalamnya pariwisata yang bernuansa edukasi dan lingkungan seperti ekowisata. Ekowisata merupakan bentuk wisata yang dikelola dengan pendekatan konservasi (Fandeli \& Mukhlison, 2000). Konservasi merupakan upaya menjaga kelangsungan pemanfaatan sumberdaya alam untuk kini dan masa mendatang. Pendekatan lainnya adalah ekowisata harus dapat menjamin kelestarian lingkungan. Maksud menjamin kelestraian seperti menjaga tetap berlangsungnya proses ekologis yang tetap mendukung sistem kehidupan, melindungi keanekaragaman hayati, serta menjamin kelestarian dan pemanfaatan spesies dan ekositemnya. Ekowisata merupakan alternatif wisata fantasi yang banyak diminati karena manfaatnya yang bersifat alami, segar, relatif murah, dan relatif mudah dalam pemeliharaan. Kegiatan wisata alam dilakukan masyarakat biasanya dengan tujuan memperoleh suasana baru yang lebih menyenangkan dan menyegarkan sehingga kepenatan yang ditimbulkan akibat rutinitas hidup dapat dihilangkan, minimal berkurang dengan harapan setelah berwisata semangatnya kembali pulih untuk menghadapi rutinitas berikutnya. Keberadaan ekowisata dalam era pembangunan berwawasan lingkungan merupakan suatu misi pengembangan pariwisata alternatif yang tidak banyak menimbulkan dampak negatif, baik terhadap lingkungan maupun terhadap sosial budaya dan daya tarik wisata lainnya. Kegiatannya lebih berorientasi pada pemanfaatan sumberdaya alami, asli dan belum tercemar. Pembangunan pariwisata baik wisata alam mmaupun buatan, sekarang sudah menjadi kebutuhan, melakukan penilaian ekonomi terhadap biaya yang dikeluarkan dapat memberikan gambaran bagi wisatawan untuk membandingkan harapan yang diinginkan dengan kenyataan yang diterima dari jasa wisata gambaran ini bisa dijadikan dalam program pengembangan pariwisata. Nilai (value) merupakan persepsi seseorang; adalah harga yang diberikan oleh seseorang terhadap sesuatu pada suatu tempat dan waktu tertentu. Kegunaan, kepuasaan dan kesenangan merupakan istilah-istilah lain yang diterima dan berkonotasi nilai atau harga. Ukuran harga ditentukan oleh waktu, barang, atau uang yang akan dikorbankan seseorang untuk memiliki atau menggunakan barang atau jasa yang diinginkannya. Penilaian (valuasi) adalah kegiatan yang berkaitan dengan pembangunan konsep dan metodologi untuk menduga nilai barang dan jasa (Davis, Johnson \& Davis, 1987). Penilaian peranan ekosistem, termasuk kawasan konservasi, bagi kesejahteraan manusia merupakan pekerjaan yang sangat kompleks, mencakup berbagai faktor yang berkaitan dengan nilai sosial dan politik. Eksistensi wisata hutan (ekowisata) sebagai produk wisata memberikan peran sangat penting bagi kontribusi industri pariwisata nasional sekaligus dampaknya terhadap perekonomian suatu Negara. Dampak berganda yang ditimbulkan pengeluaran wisatawan mancanegara dan nusantara cukup signifikan. Sektor industri pariwisata pada tahun 2005 memberikan kontribusi 5,27 persen terhadap produk domestik bruto. Dengan demikian pembangunan pariwisata perlu mendapatkan perhatian khusus bagi pemerintah khususnya wisata alam (ekowisata), dengan kegiatan wisata bisa ditingkatkan jadi perjalanan bisnis dan investasi. Pariwisata bisa menjadi alat untuk memacu Foreign Direct Investement (FDI), sehingga multipier effect terhadap kegiatan perekonomian semakin meningkat. Dampak positif yang ditimbulkan pariwisata terhadap perekonomian bukan hanya dari pengeluaran/konsumsi wisatawan mancanegara. Pengeluaran wisatawan nusantara dan pengeluaran wisatawan outbound (wisatawan Indonesia ke luar negeri) ketika mereka akan berangkat dan setelah kembali juga cukup besar dampaknya. Begitu juga investasi yang dilakukan industri pariwisata seperti hotel dan restoran serta pengeluaran pemerintah pusat dan daerah di sektor pariwisata turut memberi dampak yang besar terhadap perekonomian Indonesia. Dengan demikian berarti pertumbuhan sektor pariwisata juga mendorong laju pertumbuhan sektorsektor lain termasuk pertanian. Secara agregat dampak pariwisata terhadap ekonomi dapat berupa pembentukan output nasional, Produk Domestik Bruto (PDB), pembayaran upah/ gaji, penerimaan pajak dan penyerapan tenaga kerja. Konsep Dampak Ganda (multiplier effect) didasarkan pada hubungan berbagai sektor pembentuk ekonomi yang saling terkait serta memiliki ketergantungan dalam ekonomi lokal. Oleh karenanya, setiap perubahan pada tingkat pengeluaran wisatawan, sebagai salah satu sektor pembentuk ekonomi, akan mempengaruhi industri barang dan jasa. Setiap perubahan seperti pengeluaran wisatawan berpengaruh terhadap tingkat pengeluaran (output), nilai tambah, upah/gaji, ketenagakerjaan (employment), penerimaan negara (government revenue) dan neraca pembayaran. Rasio perubahan dalam setiap variabel di atas terhadap perubahan dalam permintaan akhir (dalam hal ini pengeluaran wisatawan) disebut pengganda (multiplier). Perkembangan kunjungan wisatawan secara otomatis merupakan pertumbuhan industri pariwisata. Dampak tak langsung mengacu pada kelanjutan dari 
kebutuhan sebuah industri yang mengalami peningkatan permintaan produknya untuk melakukan pembelian dari industri lain yang terkait. Misalnya hotel yang mendapat tamu wisatawan akan membayar gaji atau membeli barang keperluan hotelnya dari pedagang alat rumah tangga. Permintaan dari hotel ini merupakan derivative demand yang tidak berhenti pada pedagang saja tetapi akan terus berlanjut sampai industri hulunya. Dampak ikutan terjadi karena peningkatan pendapatan, akibat peningkatan permintaan akhir, sebagian akan dibelanjakan untuk konsumsi barang dan jasa yang tidak berkaitan dengan permintaan akhir tersebut Penjual souvenir akan membelanjakan sebagian pendapatannya untuk memperbaiki rumah, menyekolahkan anak, membeli barang elektronik dan sebagainya. Makin banyak yang dibelanjakan oleh industri pariwisata dan industri terkait untuk berbagai jenis barang dan jasa, makin besar dampak ikutan dari sektor pariwisata. Pemasok barang dan jasa akan meningkat pendapatannya. Peningkatan pendapatan ini akan mendorong lebih lanjut perekonomian masyarakat sehingga kesempatan kerja dan pendapatan makin lama makin meningkat. Salah satu kawasan obyek wisata di Jawa Timur yang menarik adalah beberapa Wisata di Kabupaten Banyuwangi. Daerah tersebut memiliki potensi daya tarik ekowisata yang cukup menarik. Menyajikan panorama yang memikat dalam nuansa alam pedesaan dipadu dengan keindahan hamparan gunung membentuk suasana asri dan menyejukkan serta pantai-pantai nan indah yang bisa digunakan berselancar oleh wisatawan asing maupun domestik seperti Pantai Plengkung (G-Land), Pantai Grajagan, Pantai Suka Made dengan binatang penyunya, serta wisata kawah Gunung Ijen memiliki beberapa lokasi ideal yang bisa digunakan sebagai rekreasi keluarga, perkemahan, dan acara rapat serta seminar pada institusi. Wisata kawah Gunung Ijen memiliki fungsi yang sangat strategis di samping sebagai sumber pendapatan asli daerah juga mempunyai peranan yang sangat dominan dalam memacu dan menggerakkan sektor ekonomi lainnya. Prisnsip-prinsip ekowisata diharapkan dapat meningkatkan kepedulian, komitmen dan tanggung jawab terhadap konservasi alam dan warisan budaya, menyediakan interpretasi yang memberikan peluang kepada wisatawan untuk menikmati alam dan meningkatkan kecintaanya terhadap alam, memberikan kontribusi secara kontinu terhadap masyarakat setempat serta memberdayakan masyarakat setempat dan terpenting adalah memberikan kepuasan kepada konsumen pengguna jasa wisata di Banyuwangi. Berdasarkan pengamatan, ekowista di Banyuwangi memiliki potensi besar yang cukup menarik serta memenuhi syarat untuk dikembangkan sebagai satu pengelolaan ekowisata karena memiliki keindahan dan keaslian alam serta sifat khusus lingkungan yang indah, menarik dan dapat menunjang kegiatan rekreasi. Lebih-lebih sekarang ini daerah Banyuwangi sedang mengembangkan konsep tiga berlian antara Pantai Plengkung, Kawah Gunung Ijen dan Pantai Sukamade yang nantinya akan menjadi ikon pariwisata di Banyuwangi, untuk mendukung program tersebut, diperlukan studi mengenai estimasi manfaat dan permintaan jasa ekowisata serta dampaknya terhadap perekonomian daerah di Wisata Banyuwangi.

Penelitian ini bertujuan mengidentifikasikan dan melakukan valuasi moneter manfaat yang diterima dari ekowisata (obyek wisata alam), memprediksi nilai ekonomi jasa ekowisata di Kabupaten Banyuwangi dengan pendekatan travel cost, menganalisa dampak pariwisata (ekowisata) Kabupaten Banyuwangi terhadap perekonomian daerah dengan pendekatan I-O.

\section{LANDASAN TEORI DAN HIPOTESIS}

\section{Ekowisata dan Valuasi Ekonomi Dengan Travel Cost}

Ekowisata (eco-tourism) disebutkan di UndangUndang No. 5 tahun 1990 pasal 16 sebagai kelompok-kelompok obyek dan daya tarik wisata, yang diperkuat oleh Peraturan Pemerintah No. 18 tahun 1994, sebagai perjalanan untuk menikmati gejala keunikan alam di taman nasional, hutan raya, dan taman wisata alam. Lascurain dan Ceballos (1988) menyatakan bahwa ekowisata lebih menekan pada sesuatu faktor yang The Ecotourism Society (1993) memberikan definisi sebagai suatu wisata yang bertanggungjawab ke lingkungan alami yang memberikan kontribusi pada konservasi dan kesejahteraan penduduk. Ziffer (1989) berhubungan dengan sejarah dan budaya, Hughes (1995) dan Whelan (1991) pada faktor suku dan budaya. Boo (1990) terkait invorenment education, Steele (1993) tentang kegiatan ekonomi, Cater and Lowman (1994) berOhubungan pada pemanfaatan lingkungan seperti ecotour, ecotravel, ecosafari, ecovacation, ecocruise. Ekowisata meruapakan wisata yang mengutamakan faktor pelestarian, untuk petualangan dan faktor pengetahuan dan konservasi, (Lindberg 1991, Gunn 1994, Brandon 1996). Caulkins, Bishop dan Bouwes (1986) melakukan valuasi dari perbaikan kualitas air pada tempat rekreasi dengan menggunakan metode travel cost. Dalam studinya Caulkins, Bishop dan Bouwes (1986) menggunakan Multiple Logit Model 
(MNL) dan Alternative Travel Cost Model (ATC). Penggunaan MNL ternyata menghasilkan prediksi kenaikan kurva demand rekreasi yang lebih kecil dibandingkan ATC. Hal ini karena asumsi yang digunakan berbeda. Dalam MNL diasumsikan ada pergeseran kunjungan dari suatu tempat ke tempat yang mengalami perbaikan. Sementara dalam ATC tidak ada realokasi kunjungan ke lain tempat. Smith, Desvousges dan Fisher (1986) lebih luas melakukan komparasi valuasi benefit rekreasi metode Indirect (travel cost) baik yang menggunakan Generalized Travel Cost Model (Marshallian serta Hicksian) serta Simple Travel Cost Model dengan Direct Model (Contingent Valuation) baik menggunakan teknik direct question, payment card serta iterative bidding. Hasilnya mengindikasikan estimasi yang hampir sama saja.

Kling (1988) dalam studinya mempertanyakan realibilitas estimasi benefit dari recreational demand model. Dengan menguji berbagai model, Kling menemukan bahwa pemilihan bentuk fungsi dan spesifikasi model merupakan faktor penting dalam estimasi benefit.

\section{Model Input-output}

Pengganda output yaitu dampak peningkatan permintaan akhir suatu sektor di suatu wilayah. Pengganda output sederhana adalah kenaikan permintaan akhir suatu sektor dalam perekonomian suatu wilayah terhadap kenaikan output sektor yang lain baik secara langsung maupun tidak langsung. Pengganda output total yaitu dampak kenaikan permintaan akhir suatu sektor dalam perekonomian suatu wilayah terhadap kenaikan output sektor yang lain baik langsung maupun tidak langsung dan dampak induksinya. Perlunya analisis I-O menyajikan gambaran rinci mengenai struktur ekonomi pada suatu kurun waktu tertentu, memberikan gambaran lengkap mengenai aliran barang, jasa dan input antar sektor alat peramal mengenai pengaruh suatu perubahan situasi/kebijakan ekonomi. Ide perhitungan keterkaitan antar sektor dipelopori oleh Francois Quesnay (1758) dalam Jensen \& West (1986). Table Economique diperkenalkan oleh Wassily Leontief (1966) dalam Miller \& Blair (1985), lalu dikembangkan oleh Chenery \& Watanabe (1958), Hirschman (1958) dalam Polenske (1989). Tabel input output (I-O) adalah suatu sistem informasi statistik yang disusun dalam bentuk matriks yang menyajikan informasi tentang transaksi barang dan jasa serta saling keterkaitan antara sektor yang satu dengan yang lainya (inter industry relationship) dalam suatu wilayah pada suatu periode waktu tertentu. Dalam model ekonomi makro dikenal istilah pengganda (multiplier) yang dipakai untuk menjelaskan dampak yang dialami suatu variabel endogen akibat terjadinya perubahan pada variabel eksogen. Dalam model I-O multiplier ini dapat disajikan secara simultan dalam bentuk matrik pengganda. Matriks pengganda digunakan untuk melakukan analisis dampak, yaitu: analisis dampak terhadap output, nilai tambah bruto, upah/ gaji dan tenaga kerja dan analisis keterkaitan ke depan dan ke belakang (forward dan backward linkages).

\section{METODE PENELITIAN}

Penelitian ini mengambil lokasi di wilayah Kabupaten Banyuwangi, yang didasarkan atas beberapa pertimbangan yaitu: (1) Kabupaten Banyuwangi dengan luas wilayah hanya 5.782,50 KM, tetapi memiliki aktivitas perekonomian unik yang berbeda dibandingkan perekonomian Kabupaten lain, sehingga pantas menjadi sebuah obyek penelitian semacam ini; (2) Dalam pembangunan ekonomi, Kabupaten Banyuwangi memberikan prioritas pada sektor pertanian, pariwisata dan industri, tanpa mengabaikan sektor-sektor lainnya. Dengan makin maju dan berkembangnya kepariwisataan, membawa dampak terhadap kinerja perekonomian Banyuwangi, utamanya terhadap peningkatan pendapatan regional, di mana sebagian pendapatan regional ini dampak dari bergeliatnya usaha-usaha kecil pada sektor pariwisata; (3) Belum pernah dilakukan penelitian serupa oleh peneliti-peneliti sebelumnya, sehingga dipandang perlu dilakukan penelitian semacam ini.

\section{Teknik Pengumpulan data}

Data yang dikumpulkan dalam penelitian dalam penelitian ini mencakup data primer dan data skunder. Data primer data yang diperoleh secara langsung dari responden. Data primer dikumpulkan dengan cara wawancara dengan responden dengan langsung menggunakan daftar pertanyaan yang telah disediakan dan pengamatan langsung di lapang. Data sekunder meliputi kondisi umum ekowisata di Banyuwangi yang dikumpulkan melalui penelaahan peta, laporan penelitian, terutama dari Dinas Kehutanan, Kanwil Kehutanan, Balai Konservasi Taman Nasioanl Banyuwangi, Badan Pusat Statistik dan Dinas pariwisata hal ini dilakukan karena pada penelitian Kabupaten Banyuwangi belum memiliki Tabel I-O.

Pengambilan sampel dilakukan di lapangan dengan mengggunakan metode by accident terhadap sejumlah pengunjung ekowisata yang di banyuwangi 
yang ditemui dilokasi sebanyak 300 responden. Untuk mempermudah peghitungan pengeluaran pengunjung penelitian membedakan asal pengunjung dari berbagai wilayah di Jawa Timur.

Mencermati judul penelitian ini, ingin mengetahui dampak usaha kecil pada sektor pariwisata terhadap peningkatan output sektor-sektor ekonomi dan pendapatan daerah Banyuwangi, menggiring asosiasi kita ke cakupan ekonomi makro Banyuwangi, sehingga penelitian ini tidak bersifat kasus atau parsial, tapi bersifat makro yaitu Banyuwangi. Oleh karena itu data yang diperlukan adalah data sekunder ekonomi makro Banyuwangi yaitu data PDRB Kabupaten Banyuwangi 2002-2010, Banyuwangi dalam angka, data Tinjauan Perekonomian Banyuwangi Tahun 2005-2010, data Pariwisata Banyuwangi 2010 data Propeda Kabupaten Banyuwangi, Evaluasi Pelaksanaan Pembangunan Banyuwangi Tahun 2010. Sumber data yakni Badan Pusat Statistik Kabupaten Banyuwangi, Bappeda Kabupaten Banyuwangi, Dinas Pariwisata Banyuwangi, dan beberapa instansi lain.

\section{Pendugaan Nilai Ekonomi}

Untuk menentukan faktor-faktor sosial ekonomi yang berpengaruh terhadap permintaan produk dan produk dari jasa lingkungan rekreasi wisata alam taman hutan raya digunakan analisis linier berganda. Model yang digunakan adalah model log, sebab koefisien regresi dari model $\log$ merupakan nilai elastitas, dan elastisitasnya bersifat konstan. Di sisi lain pentransformasian ke dalam bentuk logaritma adalah untuk mengurangi situasi heteroskedastisitas (Gujarati, 1988).

Model umum regresi linier berganda adalah:

$$
\begin{aligned}
\operatorname{Ln} Q i= & \beta o+\beta 1 \operatorname{LnX} X 1 i+\beta 2 \operatorname{LnX} X 2 i+\ldots . . \beta n \operatorname{LnXni} \\
& +\mu_{i}
\end{aligned}
$$

keterangan:

$Q \quad=$ Peubah Tak Bebas (nilai ekonomi)

$X 1,2, \ldots n=$ Peubah Bebas (faktor sosial ekonomi)

$\mathrm{i} \quad=$ Rumah tangga ke $\mathrm{i}$

$\mu \quad=$ Gangguan

$\beta 1,2, \ldots . n=$ Koefisien Regresi

$\beta 0=$ Intersep

Penentuan faktor-faktor yang dimasukan ke model digunakan uji stepwise regresi. Pengujian ada tidaknya multikolinearitas digunakan metode klein. Pengujian autokorelasi digunakan metode GoldfeldQuandt. Untuk mengetahui pengaruh tiap-tiap peubah digunakan uji $\mathrm{T}$, sedangkan untuk mengetahui pengaruh peubah secara keseluruhan digunakan uji $\mathrm{F}$. Berdasarkan pada teori bahwa nilai penyediaan suatu barang atau jasa dapat didekati oleh total kesediaan membayar dari para konsumen (Darusman, 1993). Total kesediaan membayar merupakan daerah yang berada di bawah kurva permintaan, dan permintaan suatu produk dipengaruhi oleh faktor-faktor sosial ekonomi rumah tangga. Dengan demikian, faktorfaktor sosial ekonomi digunakan dalam perhitungan nilai ekonomi ekosistem taman hutan raya. Adapun langkah-langkah perhitungannya adalah sebagai berikut: Langkah pertama, menghitung intersep baru ( $\beta$ ') dari fungsi permintaan, cara perhitungannya adalah:

$$
\begin{aligned}
& \operatorname{Ln} Q=\beta o+\beta 1 \operatorname{Ln} X 1+\beta 2(\operatorname{Ln} X 2 i)+\ldots . . \beta n(\operatorname{Ln} \\
& X n) \\
& \operatorname{Ln} Q=((\beta o+\beta 2(\operatorname{LnX} X))+\ldots . . \beta n(\operatorname{Ln} X n)+\beta 1 \\
& \text { LnX1 } \\
& \operatorname{Ln} Q=\beta^{\prime}+\beta 1 \operatorname{Ln} X 1
\end{aligned}
$$

Langkah selanjutnya, mengembalikan persamaan di atas ke fungsi asal, dan kemudian mentransformasikan fungsi asal, yang mana persamaan berubah menjadi peubah tak bebas X1 dan peubah bebas Q. Smith, Desvousges dan Fisher (1986) memberikan cara menduga utiliti atau kesediaan membayar dengan menggunakan persamaan matematik, yaitu :

$$
U=\int_{0}^{a} f(q) d Q
$$

keterangan:

$U=$ Utiliti (kesediaan membayar)

$f(Q)=$ Fungsi permintaan

$\mathrm{a}=$ Rata-rata jumlah produk yang dikonsumsi

Field (1984) memberikan batas atas dari integral adalah jumlah barang yang dikonsumsi, sedangkan Darusman (1993), memberikan batas atas adalah ratarata jumlah barang yang dikonsumsi. Smith, Desvousges dan Fisher (1986) menyatakan bahwa total kesediaan membayar sama dengan total harga yang dibayar ditambah total surplus konsumen. Perhitungan total nilai ekonomi, surplus ekonomi dan harga yang dibayarkan dari setiap produk dilakukan dengan menggandakan produk atau produk dari jasa lingkungan yang dihasilkan

\section{Nilai Ekonomi Rekreasi Ekowisata di Banyu- wangi}

Nilai ekonomi rekreasi diduga dengan menggunakan metode biaya perjalanan wisata (travel cost method), yang meliputi biaya transport pulang pergi dari tempat tinggalnya ke wisata di beberapa wisata 
Banyuwangi, dan pengeluaran lain selama di perjalanan dan di dalam Wisata di Banyuwangi, (mencakup dokumentasi, konsumsi, parkir, karcis masuk).

Untuk mengetahui kurva permintaan, dibuat model permintaan yang merupakan hubungan antara jumlah kunjungan per seribu penduduk daerah asal (zona) pengunjung dengan biaya perjalanan. Langkah-langkah yang dilakukan dalam menentukan fungsi permintaan tersebut adalah (Bahruni, 1993):

1. Menentukan jumlah kunjungan tahun 2008/2009 (JKT) berdasarkan data yang ada di Dinas Pariwisata Kabupaten Banyuwangi.

2. Menduga distrubusi (persentase) daerah asal pengunjung berdasarkan sensus pengunjung di pintu masuk.

$$
P i=\frac{J C i}{n} \times 100 \%
$$

dalam hal ini:

$P i=$ Persentase kunjungan dari daerah (Zona) $\mathrm{I}$

$J c i=$ Jumlah kunjungan contoh dari Zona I

$N=$ Jumlah Total kunjungan contoh (jumlah contoh)

3. Menentukan jumlah kunjungan per tahun dari daerah (Zona) tertentu (Jki):

$J k i=P i x J K T$

4. Menentukan jumlah kunjungan dari zona tertentu per 1000 penduduk (Yi)

$Y i=\frac{J K i}{J p i} \times 1000$

5. Menentukan biaya perjalanan rata-rata dari zona tertentu $\left(\mathrm{X}_{1 \mathrm{II}}\right)$ yang ditentukan berdasarkan biaya perjalanan responden (Bpi)

$X I i=\frac{\sum_{l}^{n i} X i}{N i}$

6. Menentukan nilai ekonomi dengan kunjungan per 1000 penduduk sebagai $\mathrm{Y}$ dan biaya perjalanan wisata sebagai $X_{1}$

\section{Pengukuran Dampak Ekowisata Terhadap Per- ekonomian}

Dalam analisis dampak pariwisata terhadap kinerja ekonomi daerah dan nasional, permintaan akhir menjadi faktor eksogen yang mendorong penciptaan nilai produksi barang dan jasa. Dalam kaitannya dengan dampak pariwisata, faktor pendorong (exogenous variable) berupa konsumsi wisatawan mancanegara (inbound), wisatawan nusantara (wisnus), wisatawan Indonesia ke luar negeri (outbound) terhadap produk dalam negeri, investasi pariwisata dan pengeluaran pemerintah untuk pariwisata (APBN) serta lembaga-lembaga nirlaba yang ikut andil dalam kegiatan pariwisata. Dengan model IO dampak kepariwisataan dapat diuraikan, sebagai berikut:

\section{Dampak Terhadap Output}

Pengeluaran konsumsi pariwisata akan berdampak terhadap penciptaan nilai produksi barang dan jasa sektoral. Hubungan antara konsumsi kepariwisataan dengan nilai output dapat diformulasikan, sebagai berikut:

$$
X_{i}=\left(I-A^{d}\right)^{-1} \cdot W_{i}
$$

keterangan:

$\mathrm{X}_{\mathrm{i}} \quad=$ output yang diciptakan akibat konsumsi kepariwisatawaan.

$\left(\mathrm{I}-\mathrm{A}_{\mathrm{d}}\right)-1=$ invers matriks berfungsi sebagai koefisien regresi dalam model.

$\mathrm{W}_{\mathrm{i}} \quad=$ konsumsi kepariwisataan, mencakup 1) inbound, 2) outbound, 3) wisnus, 4) investasi pariwisata dan 5) lainnya (pemerintah dan nirlaba).

$=1,2,3,4,5$.

Persamaan (10) mendasarkan hubungan linear antara permintaan akhir, dalam hal ini konsumsi pariwisata dengan output. Semakin besar jumlah permintaan terhadap produk barang dan jasa, maka output yang harus disediakan harus bertambah mengikuti matriks pengganda sebagai koefisien regresinya. Persamaan di atas menghasilkan nilai output barang dan jasa setiap sektor akibat dari konsumsi pariwisata. Dapat diketahui dampak output akibat masing-masing komponen konsumsi pariwisata terhadap sektor-sektor ekonomi. Misalkan, pengeluaran wisman di Indonesia akan berdampak terhadap penambahan nilai produksi barang dan jasa. Demikian pula akibat wisnus, investasi pariwisata dan pengeluaran pemerintah untuk pengembangan pariwisata.

\section{Dampak Terhadap Nilai Tambah Bruto}

Nilai tambah bruto merupakan bagian dari nilai output sektor ekonomi. Sebagai balas jasa atas faktor produksi, nilai tambah bruto mencakup upah dan gaji, surplus usaha, penyusutan, pajak tak langsung dan subsidi. Sebagaimana model IO untuk menghasilkan nilai output akibat konsumsi pariwisata, nilai tambah yang diciptakan juga berbanding lurus dengan permintaan atau konsumsi kepariwisataan. Formulasi yang menunjukkan hubungan tersebut adalah sebagai berikut:

$\mathrm{V}_{\mathrm{i}}=\mathrm{v}\left(\mathrm{I}-\mathrm{A}_{\mathrm{d}}\right)-1 . \mathrm{W}_{\mathrm{i}}$

$$
=\mathrm{v} \cdot \mathrm{Xi}
$$


keterangan:

$\mathrm{V}_{\mathrm{i}}=$ nilai tambah bruto karena dampak konsumsi kepariwisataan.

$\mathrm{V}=$ matriks diagonal koefisien nilai tambah bruto, yaitu: rasio antara nilai tambah bruto sektor tertentu dengan outputnya

$\mathrm{i}=1$ ) inbond, 2) outbond, 3) wisnus, 4) investasi pariwisata dan 5) lainnya (pemerintah dan nirlaba)

Persamaan (11) menunjukkan hubungan searah antara nilai tambah bruto dengan nilai outputnya. Ini juga berarti bahwa terdapat hubungan antara konsumsi kepariwisataan dengan penciptaan nilai tambah sektor-sektor ekonomi, yaitu pengeluaran wisman, wisnus, investasi pariwisata dan lainnya.

\section{Dampak Terhadap pendapatan}

Salah satu komponen nilai tambah bruto adalah upah/gaji. Dari model I-O dapat diturunkan hubungan antara upah/ gaji dengan konsumsi kepariwisataan. Hubungan tersebut dapat disajikan sebagai berikut:

$$
\begin{aligned}
\mathrm{Gj} & =\mathrm{gj}\left(\mathrm{I}-\mathrm{A}_{\mathrm{d}}\right)-1 . \mathrm{W}_{\mathrm{i}} \\
& =\mathrm{gj} \cdot \mathrm{Xi}
\end{aligned}
$$

keterangan:

$\mathrm{Gj}=$ Upah/gaji akibat konsumsi kepariwisataan.

gj = matriks diagonal koefisien upah/gaji, yaitu rasio antara upah/gaji sektor tertentu dengan outputnya.

Persamaan ini mengindikasikan adanya keterkaitan antara konsumsi kepariwisataan dengan upah/gaji para pekerja pada sektor-sektor ekonomi.

\section{Kerangka Konseptual}

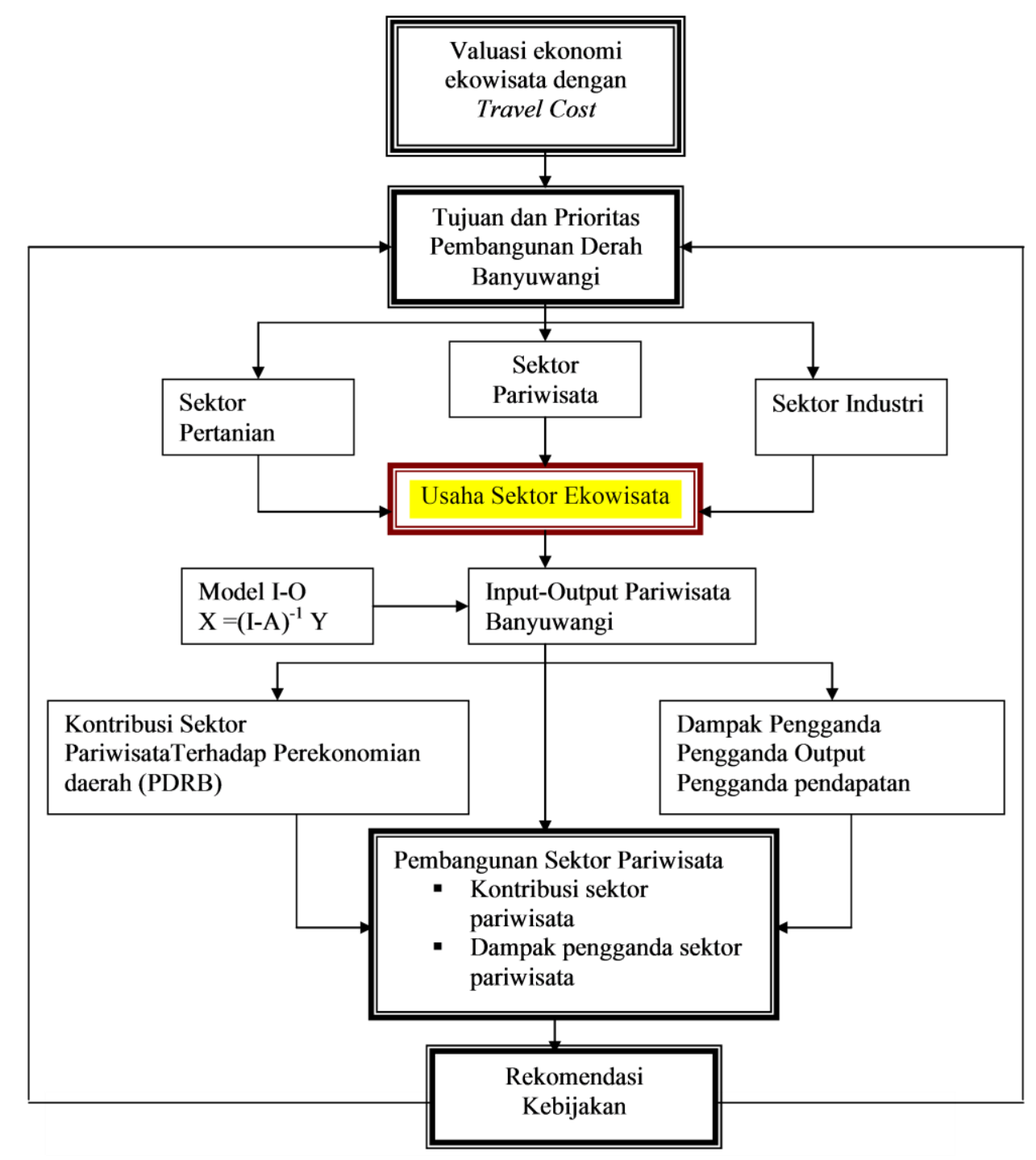

Gambar 1. Kerangka Konseptual Travel Cost dan Dampaknya pada Perekonomian Daerah 


\section{HASIL PENELITIAN DAN PEMBAHASAN}

\section{Nilai Ekonomi Wisata}

Penentuan nilai ekonomi wisata didasarkan pada pendekatan biaya perjalanan wisata, yaitu jumlah uang yang dikeluarkan seseorang selama melakukan kunjungan ekowisata di Banyuwangi. Biaya tersebut meliputi biaya transportasi pulang pergi, biaya konsumsi, biaya dokumentasi, dan lain-lain termasuk biaya karcis masuk. Biaya konsumsi yang dimaksud adalah biaya konsumsi yang dikeluarkan selama melakukan kunjungan wisata dikurangi dengan ratarata biaya konsumsi harian. Perjalanan wisata yang didasarkan pada biaya-biaya tersebut sangat tergantung pada masing-masing pengunjung dari masing-masing zona, karena masing-masing bagian berbeda. Pembagian zona dalam nilai ekonomi wisata yang sangat kecil (lima zona) dikarenakan jumlah responden yang sangat kecil dan selama penelitian berlangsung, hanya penduduk daerah tersebut yang berkunjung ke lokasi wisata. Berdasarkan wilayah asal dan biaya perjalanan wisata dari masing-masing zona dapat dilihat pada Tabel 1 .

Untuk perhitungan nilai total ekonomi wisata didapatkan dari hasil jumlah penggandaan nilai ratarata biaya perjalanan per zona dengan jumlah pengunjung dari masing-masing zona dalam satu tahun. Jumlah pengunjung masing-masing zona dalam satu tahun diduga dengan formula sebagai berikut:

Jumlah pengunjung zona $\mathrm{I}=\frac{\sum \text { pengunjung zona } i}{\Sigma \text { pengunjung total }} \times$

$\sum$ pengunjung dalam 1 tahun
Jumlah pengunjung ekowisata dalam tahun 2009-2010 adalah 2030 pengunjung dengan rincian per bulan. Ringkasan nilai ekonomi total wisata secara lengkap disajikan pada Tabel 2.

Jadi nilai ekonomi rata-rata dari wisata di Banyuwangi adalah Rp. 2.394 per pengunjung per tahun. Jika diasumsikan jumlah pengunjung pertahun 2030 x Rp. $2.394=$ Rp. $4.859 .820,00$

\section{Sektor Ekowisata (Usaha Kecil Pariwisata) Terhadap Pendapatan Regional Banyuwangi}

Pendapatan Daerah Banyuwangi dalam pengertian pendapatan regional Banyuwangi (PDRB) yang bersumber dari berbagai aktivitas ekonomi, termasuk aktivitas pada industri pariwisata dapat diklasifikasikan ke dalam sektor-sektor ekonomi. Misal, masyarakat dan pengusaha yang bekerja pada restoran, rumah makan dan warung dengan metode perhitungan nilai tambah bruto, pendapatannya dikelompokkan ke dalam sektor restoran, rumah makan dan warung. Jadi perhitungan pendapatan regional dengan metode nilai tambah adalah penjumlahan balas jasa dari faktor-faktor produksi yang dimiliki masyarakat Banyuwangi, yang diklasifikasikan ke dalam 9 sektor, seperti sektor-sektor perekonomian dalam PDRB untuk tingkat regional atau PDB untuk tingkat nasional. Nilai tambah bruto (NTB) atau input primer merupakan balas jasa atas pemakaian faktor-faktor produksi yang terdiri dari tenaga kerja, tanah, modal dan kewiraswastaan. Input primer ini terdiri dari; (a) upah dan gaji, (b) surplus usaha, (c) penyusutan

Tabel 1. Rata-Rata Biaya Perjalanan Wisata Pengunjung Ekowisata Dari Masing-Masing Zona

\begin{tabular}{lcccc}
\hline \multirow{2}{*}{ Zona } & \multicolumn{4}{c}{ Besarnya biaya (Rp/orang/kunjungan) } \\
\cline { 2 - 4 } & Transport PP & Konsumsi & Lain-lain & Total $^{\text {2) }}$ \\
\hline 1. Banyuwangi & 19833,33 & 5277,78 & 14388,89 & 39500 \\
2. Jember & 24166,67 & 12083,33 & 11479,17 & 47729 \\
3. Malang & 44583,33 & 11000,00 & 28500,00 & 84083 \\
4. Sidoarjo & 75000,00 & 10000,00 & 3250,00 & 88250 \\
5. Surabaya & 90000,00 & 62500,00 & 40750,00 & 193250 \\
\hline
\end{tabular}

Keterangan: ${ }^{1)}$ termasuk harga karcis masuk, ${ }^{2)}$ angka dibulatkan

Sumber: Analisa Data Primer, 2010

Tabel 2. Ringkasan Nilai Ekonomi Total Ekowisata

\begin{tabular}{llccc}
\hline No & Zona & $\begin{array}{c}\text { Rata-rata biaya } \\
\text { perjalanan }(\mathbf{R p})\end{array}$ & $\begin{array}{c}\text { Jumlah pengunjung } \\
\text { (orang) }\end{array}$ & $\begin{array}{c}\text { Nilai Ekonomi Total *) } \\
(\mathbf{R p})\end{array}$ \\
\hline 1. & Banyuwangi & $45.500,00$ & 762 & $27.149 .000,00$ \\
2. & Jember & $53.729,17$ & 984 & $47.056 .336,00$ \\
3. & Malang & $94.083,33$ & 119 & $9.265 .083,00$ \\
4. & Sidoarjo & $95.250,00$ & 96 & $6.807 .000,00$ \\
5. & Surabaya & $203.250,00$ & 339 & $47.186 .750,00$ \\
Jumlah & & & $153.264 .169,00$ \\
\hline
\end{tabular}

$*$ ) = Sampel x Populasi, angka dibulatkan

Sumber: Analisis Data Primer, 2010 
barang modal, (d) pajak tak langsung neto. Besarnya NTB perekonomian Banyuwangi tahun 2010 juga merupakan Produk Domestik Regional Bruto (PDRB) Banyuwangi untuk periode tersebut. Namun, dalam Tabel Input-Output Pariwisata Banyuwangi Tahun 2010 yang diagregasi menjadi 33 sektor, dimaksudkan agar sektor-sektor jasa yang terkait dengan industri pariwisata tampil lebih rinci, seperti sektor restoran, warung dan rumah makan, sektor hotel non bintang, dan lain-lain.

Artinya sumbangan masing-masing sektor tersebut terhadap nilai tambah bruto daerah Banyuwangi merupakan penjumlahan dari pendapatan masyarakat dan pengusaha yang bekerja pada masing-masing sektor tersebut. Dari hasil perhitungan Tabel InputOutput Pariwisata Banyuwangi Tahun 2010 yang terdiri dari 33 sektor, diperoleh bahwa sektor-sektor pendukung industri pariwisata (sektor 17, 18, 19, 22, 23, 24, 28, 32 dan 33) mendominasi pembentukan NTB perkonomian Banyuwangi untuk tahun 2010 yakni sebesar Rp 5.328.136 juta atau 33,12\% dari total NTB Banyuwangi tahun 2010. Belum terhitung lagi sektor-sektor lain yang sebagian aktivitasnya mendukung kelancaran industri pariwisata, seperti sektor perdagangan (besar dan eceran), angkutan darat dan laut, komunikasi, pos dan giro, perbankan dan lembaga keuangan lainnya, maka peranan industri pariwisata Banyuwangi menjadi semakin besar. Jadi temuan ini menjastifikasi pernyataan sebelumnya bahwa perekomian daerah Banyuwangi sangat didominansi oleh industri atau sektor pariwisata. Namun dari 9 sektor yang mendukung langsung industri atau sektor pariwisata Banyuwangi, 3 sektor yang memilki kontribusi besar yaitu sektor hotel sebesar $12,32 \%$, sektor restoran, rumah makan dan warung sebesar $8,14 \%$ dan sektor jasa perorangan, rumah tangga lainnya termasuk pramuwisata sebesar 5,97\% (tabel 2). Namun jika dicermati sektor-sektor pendukung pariwisata yang menampung usaha-usaha kecil atau usaha kecil pada sektor pariwisata memiliki kontribusi bersama sebesar $\mathrm{Rp}$ 2.694.049 juta atau 16,3\% dari total pendapatan regional Banyuwangi (total Nilai Tambah Bruto) (Tabel 2). Pada Tabel 2 juga dihitung koefisien input primer (KIP) ke 33 sektor ekonomi. Bila mengacu kriteria Riyanto (1997), apabila suatu sektor memiliki koefisien input primer $(\mathrm{KIP}) \geq 0,5$ berarti secara teknis sektor tersebut mampu bekerja secara efisien. Implikasinya sektor yang bersangkutan mampu menciptakan upah dan gaji, surplus usaha dan pajak tidak langsung yang besar. Pada Tabel 6 tampak bahwa ada enam sektor yang memiliki KIP besar serta memberikan kontribusi tertinggi. yaitu: sektor hotel bintang (18), perdagangan (16), pertanian (1), restoran, rumah makan, warung (17), jasa umum dan sosial (31), jasa perseorangan, rumah tangga lainnya, termasuk pramuwisata (33). Di samping sektor-sektor dominan tadi, sebaliknya ada satu sektor yang tidak memberikan kontribusi terhadap perekonomian daerah Banyuwangi yaitu sektor bahan bakar minyak (11) dengan nilai kontribusi sebesar Rp. 0,- atau $0,00 \%$ serta dengan KIP $=1$ berarti walaupun sektor ini efisien dari segi KIP yang dihasilkan, tetapi sektor ini tidak memberikan kontribusi terhadap perekonomian Banyuwangi.

Hal ini disebabkan bahan bakar minyak tidak melibatkan faktor-faktor produksi yang ada di daerah, sehingga balas jasanya terhadap faktor produksi tidak ada. Nampaknya penguasaan bahan bakar minyak ini dominan dikuasai oleh pemerintah (Pertamina) pusat. Namun sektor-sektor pariwisata yang menampung usaha-usaha kecil $(17,19,22,24,28,32$ dan 33) memiliki koefisien input primer (KIP) bervariasi dari 0,370 untuk travel biro (terkecil) sampai dengan 0,823 untuk atraksi budaya (terbesar) dengan KIP rata-rata sebesar 0,618. Jika KIP usaha kecil ini dihubungkan dengan kriteria Riyanto (1997), maka usaha kecil pada sektor pariwisata termasuk efisien, karena mampu menciptakan upah, gaji, surplus usaha dan pajak tidak langsung yang besar, yang berarti pula mampu menjadi mesin penggerak perekonomian daerah Banyuwangi, khususnya aktivitas-aktivitas masyarakat yang terkait langsung dan tidak langsung terhadap kedua sektor tersebut.

Jika nilai tambah bruto (NTB) sektor-sektor perekonomian Banyuwangi tahun 2010 dijabarkan menurut komponen penggunaannya, maka teralokasi pada komponen upah dan gaji $32,73 \%$, surplus usaha $54,83 \%$, pajak tidak langsung $4,20 \%$ dan penyusutan $8,23 \%$. Penggunaan PDRB yang relatif dominan pada komponen surplus usaha, hal ini memunjukkan bahwa nilai tambah yang terbentuk dalam perekonomian Banyuwangi sebagian besar diperuntukkan sebagai balas jasa atas kewiraswastaan dan pendapatan para pemilik modal. Rasio upah dan gaji dengan surplus usaha sebesar 59,69\%. Rasio ini akan semakin baik, jika mendekati keseimbangan. Semakin besar rasio ini menunjukkan besarnya upah dan gaji yang diterima oleh tenaga kerja sektor yang bersangkutan dibandingkan surplus yang diterima oleh produsen. Sebaliknya apabila rasio ini semakin kecil, menunjukkan terjadi penghisapan oleh pengusaha terhadap para karyawan atau pekerjanya .

Berdasarkan data input-output tahun 2010, jumlah nilai Permintaan Akhir (PA) oleh sektorsektor perekonomian Banyuwangi adalah sebesar Rp. 20.824.361 juta. Dari jumlah tersebut, sebesar $35,00 \%$ diminta oleh industri pariwisata untuk 
memenuhi permintaan barang dan jasa hotel (18), restoran, rumah makan, warung (17), perdagangan (16). Sektor-sektor ekonomi lainnya yang dapat dimasukkan sebagai sepuluh besar dalam memberikan kontribusi terhadap permintaan akhir adalah bangunan/kontruksi (15), industri pengolah hasil pertanian (7), jasa umum dan sosial (31), peternakan (3), industri tekstil dan pakaian jadi (8), angkutan udara (23), dan jasa perorangan, rumah tangga lainnya termasuk pramuwisata (33). Di samping sektor-sektor dominan tadi yang relatif besar kontribusinya terhadap pembentukan permintaan akhir, sebaliknya masih terdapat banyak sektor yang hanya mampu menyumbang atau memberikan kontribusi di bawah $1 \%$ yakni perbankan dan lembaga keuangan lainnya (27), industri kimia, barang dari kimia karet dan plastik (10), hotel non-bintang (19), komunikasi, pos dan giro (26), angkutan wisata (22), bahan bakar minyak (11), jasa penunjang angkutan lainnya (25), angkutan laut (21), atraksi budaya dan hiburan lainnya (32), perkebunan (2), money changer (28), jasa perusahaan (30), industri kerajinan, bahan galian, bahan bangunan (12), kehutanan (4), pertambangan dan penggalian (6). Mencermati permintaan akhir oleh sektor-sektor perekonomian, utamanya usaha kecil pada sektor pariwisata, maka tampak usaha kecil ini mampu menciptakan permintaan akhir atau permintaan barang dan jasa yang langsung dikonsumsi, seperti permintaan berbagai produk pertanian dalam arti luas sebesar Rp. 4.030.330 juta atau sebesar 19,36\% dari total permintaan akhir .

Implikasinya bahwa sektor pertanian termasuk petaninya akan terangsang untuk meningkatkan produksinya dalam usaha memenuhi peningkatan permintaan untuk dikonsumsi langsung oleh usaha-usaha kecil pada sektor pariwisata.

\section{Dampak Pengganda Usaha Kecil Pariwisata}

Dampak usaha kecil sektor pariwisata terhadap peningkatan pendapatan regional yang dimaksud di sini adalah dampak pengganda usaha kecil pada sektor pariwisata, baik dampak pengganda output maupun dampak pengganda pendapatan. Artinya setiap perubahan (peningkatan/penurunan) satu unit moneter usaha kecil pada sektor pariwisata akan mampu meningkatkan output atau pendapatan sektorsektor ekonomi lainya Di dalam menganalisis ekonomi suatu wilayah, koefisien dampak pengganda penting untuk diketahui mengingat peranannya sebagai indikator perkembangan perekonomian wilayah itu sendiri. Pada dasarnya koefisien dampak pengganda merupakan nilai yang menunjukkan hasil pertambahan yang muncul sebagai akibat injeksi investasi sektoral ke dalam sistem perekonomian. Berdasarkan jenisnya, koefisen dampak pengganda dibedakan menjadi dua yaitu koefisien dampak pengganda tipe I dan koefisien dampak pengganda tipe II. Koefisien dampak pengganda tipe I menunjukkan besarnya pengaruh "permintaan akhir" suatu sektor terhadap pertumbuhan sistem perekonomian, di mana komponen rumah tangga bertindak sebagai variabel eksogenus. Nilai koefisien pengganda tipe II menunjukkan hal yang sama, tetapi komponen rumah tangga bertindak sebagai variabel endogenus. Di dalam penelitian ini sesuai data yang ada, dampak tersebut hanya dapat digambarkan dalam dua model yaitu dampak pengganda output dan dampak pengganda pendapatan. Setiap dampak pengganda dalam model input-output dapat dibedakan dalam beberapa kategori, yaitu; Pertama, dampak awal (initial impact). Kedua, dampak imbasan kegiatan produksi (production induced impact), yang terdiri dari: pengaruh langsung (direct effect) atau juga disebut pengaruh putaran pertama (first round effect) dan pengaruh tidak langsung (indirect effect) yang merupakan pengaruh putaran kedua dan seterusnya atau yang dikenal dengan pengaruh dukungan industri (industrial-support effect), serta dampak imbasan konsumsi (consumption induced effect). Penjumlahan dampak awal dengan dampak imbasan tersebut dikenal dengan dampak pengganda total (total multiplier effect). Di samping itu terdapat kategori lainnya yang disebut dengan dampak luberan (flow-on impact) yang merupakan dampak bersih. Kategori pengganda yang disebutkan terakhir ini akan sangat berperan guna menentukan sektor-sektor pendukung bagi sektor prioritas dengan analisis pengganda.

\section{Pengganda Output}

Sebagaimana dijelaskan pada bagian sebelumnya, dalam analisis dampak pengganda output, koefisien initial effect selalu sama dengan satu, sehingga untuk mendapatkan nilai pengganda output riil dalam analisis ini akan lebih ditekankan pada angka penggada output tipe II. Berdasarkan koefisien tipe II ini akan bisa digambarkan sektor-sektor perekonomian Daerah Banyuwangi dan sektor-sektor perekonomian yang menampung usaha kecil pariwisata yang memiliki angka pengganda tipe II lebih besar dari 2 sebagai sektor yang mampu memicu pertumbuhan ekonomi. Sektor-sektor perekonomian Banyuwangi berdasarkan data I-O Pariwisata Tahun 2010 (33 sektor) mempunyai nilai koefisien pengganda output tipe I (pengganda output sederhana) maupun pengganda output tipe II (pengganda output total). Dari data I-O diamati tampak bahwa antara 
nilai koefisien pengganda output tipe I dan tipe II memiliki perbedaan yang cukup besar, yang mana nilai tertinggi pada tipe I masih berada di bawah angka 3, sedangkan pada tipe II semua nilainya berada di atas 3, kecuali bahan bakar minyak (11). Perbedaan yang demikian disebabkan oleh penempatan komponen rumah tangga sebagai variabel endogenus pada pengganda output tipe II. Untuk dapat memberikan interpretasi terhadap angkaangka yang terdapat dalam Tabel 4, maka akan diangkat satu contoh yaitu sektor yang memiliki peringkat pengganda output tertinggi yaitu sektor peternakan (3) dengan koefisien pengganda output tipe I sebesar 2,227 dan sektor jasa umum dan sosial (31) yang memiliki koefisien pengganda output tipe II sebesar 5,871. Sektor peternakan (3) dengan koefisien pengganda output tipe I sebesar 2,227, artinya setiap peningkatan permintaan akhir oleh sektor peternakan sebesar Rp. 1.000,- akan mampu meningkatkan output sektor-sektor perekonomian lainnya di Banyuwangi sebesar Rp. 2.227,-. Peningkatan output sebesar itu disebabkan oleh, dampak awal sebesar Rp. 1.000,-, dampak langsung (direct effect) sebesar Rp.606,- dan dampak tidak langsung yaitu pengaruh dukungan industri sebesar Rp. 621,-. Kemudian untuk peringkat tertinggi pengganda output tipe II yakni 'sektor jasa umum dan sosial' (31) memiliki koefisien pengganda output tipe II sebesar 5,871. Artinya setiap terjadi peningkatan permintaan akhir pada sektor 'jasa umum dan sosial' sebesar Rp. 1.000,- akan meningkatkan output sektor-sektor ekonomi lainnya sebesar Rp. 5.871,-. Peningkatan output sebesar itu dsebabkan oleh, dampak awal sebesar Rp. 1.000,-, dampak langsung (direct effect) sebesar Rp.933,-, dampak tidak langsung yaitu pengaruh dukungan industri sebesar Rp. 3.647,- dan dampak imbasan konsumsi sebesar Rp 291,-. Bila dikaitkan dengan nilai rata-rata pengganda output tipe II seluruh sektor perekonomian Banyuwangi, maka terdapat 16 sektor yang memiliki koefisien pengganda di atas rata-rata, yaitu jasa umum dan sosial (31), peternakan (3), industri pengolah hasil pertanian (7), pertanian (1), perkebunan (2), kehutanan (4) restoran, rumah makan dan warung (17), bangunan/kontruksi (15), industri kimia, barang dari kimia, karet dan plastik (10), industri tekstil dan pakaian jadi (8), industri kerajinan kayu dan perhiasan (9), industri kerajinan, bahan galian, bahan bangunan (12), perdagangan (16), travel biro (24), hotel non bintang (19), hotel bintang (18). Bila diamati secara keseluruhan tampak bahwa sektor-sektor perekonomian Banyuwangi hampir seluruhnya memiliki nilai koefisien tipe II lebih besar dari pada dua, kecuali sektor bahan bakar minyak (11). Berdasarkan kondisi yang demikian dapat dikatakan bahwa sektor- sektor perekonomian Banyuwangi telah mampu memacu pertumbuhan output daerahnya. Dari pengganda output tipe II dapat pula digambarkan nilai induksi masing-masing sektor perekonomian Banyuwangi. Nilai induksi bisa memberikan informasi tentang peranan pola konsumsi dan pendapatan rumah tangga dalam pembangunan. Bila nilai induksi suatu sector besar, berarti hal demikian menunjukkan bahwa permintaan akan sektor tersebut oleh rumah tangga meningkat akibat adanya peningkatan pendapatan rumah tangga. Jadi sehubungan dengan penanaman investasi, sebaiknya diarahkan pada sektor-sektor yang memiliki nilai induksi terbesar untuk diberikan injeksi investasi. Beberapa sektor yang memiliki nilai induksi besar antara lain: sektor perdagangan (16), bangunan/kontruksi (15), pertambangan dan penggalian (6), atraksi budaya dan hiburan lainnya (32), industri kimia, barang dari kimia, karet dan plastik (10).Dari hasil analisis tampak bahwa sektor-sektor pendukung utama pariwisata yang menampung usaha-usaha kecil pariwisata (sektor 17, 19, 22, 24, 28, 32 dan 33) memiliki angka pengganda output tipe I rata-rata 1,631 lebih besar dari angka pengganda rata-rata umum sebesar 1,609 dan dampak pengganda output tipe II rata-rata 3,041 lebih besar dari pada 2. Ini menunjukkan bahwa sektor-sektor pendukung utama pariwisata yang menampung usaha kecil pariwisata atau usaha-usaha kecil pada sektor pariwisata memiliki kemampuan sebagai pemicu pertumbuhan ekonomi daerah Banyuwangi. Angka pengganda output tipe II rata-rata usaha kecil pada sektor pariwisata sebesar 3,041, artinya setiap peningkatan permintaan akhir usaha kecil pada sektor pariwisata $(17,19,22,24,29,32$ dan 33) sebesar satu rupiah, mampu meningkatkan output sektor-sektor ekonomi lainnya (melalui permintaan output oleh usaha-usaha kecil) dalam perekonomian daerah Banyuwangi sebesar Rp 3,041. Misalnya, hotel non bintang dengan pengganda tipe II sebesar 3,856, artinya setiap peningkatan permintaan akhir sektor hotel non bintang dari penyewaan kamarnya sebesar satu rupiah, akan mampu meningkatkan output sektorsektor ekonomi lainnya (melalui peningkatan output oleh hotel non bintang) dalam perekonomian pariwisata daerah Banyuwangi sebesar Rp 3,856,-. Namun jika dicermati dampak pengganda tipe I dan tipe II dari sektor-usaha kecil pariwisata $(17,19,22,24,28$, 32 dan 33), tampak bahwa di antara sektor-sektor tersebut memiliki dampak penganda tipe I dan tipe II yang bervariasi. Atraksi budaya dan hiburan lainnya' memiliki angka pengganda terkecil, bik untuk tipei I dan tipe II masing-masing sebesar 1,280 dan 2,612. Angkutan wisata memiliki dampak pengganda 
terbesar untuk tipe I dan tipe II masing-masing 2,050 dan 3,894 . Walau ada variasi, tetapi secara rata-rata usaha kecil pada sektor pariwisata memiliki kemampuan memicu pertumbuhan ekonomi dari permintaan yang mereka ciptakan terhadap produkproduk (Output) sektor-sektor ekonomi lainnya.

\section{Pengganda Pendapatan}

Pengganda pendapatan rumah tangga (Income Multiplier) sektor tertentu menunjukkan jumlah pendapatan rumah tangga total yang tercipta akibat adanya tambahan satu-satuan moneter permintaan akhir pada sektor tersebut. Seperti halnya pengganda output, maka sektor-sektor perekonomian Banyuwangi berdasarkan data I-O Pariwisata Tahun 2010 (33 sektor) mempunyai nilai koefisien pengganda pendapatan tipe I maupun tipe II.

Pengganda pendapatan rata-rata tipe I sektorsektor perekonomian Banyuwangi sebesar 1,738, artinya rata-rata kenaikan permintaan akhir seluruh sektor perekonomian sebesar Rp. 1000,-, maka akan meningkatkan pendapatan rata-rata masyarakat sebesar Rp.1.738,-. Sektor-sektor ekonomi yang memiliki pengganda pendapatan di atas rata-rata berarti, setiap peningkatan permintaan akhir sektorsektor tersebut sebesar satu rupiah, akan lebih besar menciptakan pendapatan terhadap sektor-sektor ekonomi lainnya dibandingkan dengan sektor-sektor yang memiliki pengganda pendapatan di bawah ratarata. Sektor-sektor perekonomian Banyuwangi yang memiliki angka pengganda pendapatan di atas ratarata adalah industri pengolah hasil pertanian (7), persewaan bangunan dan tanah (29), peternakan (3). travel biro (24), restoran, rumah makan, dan warung (17), industri kerajinan bahan galian, bahan bangunan (12), industri tekstil dan pakaian jadi (8), industri kerajinan kayu dan perhiasan (9), sektor bangunan/ konstruksi (15), industri kimia, barang dari kimia, karet dan plastik (10), perbankan dan lembaga keuangan lainnya (27), industri lainnya (13), komunikasi pos dan giro (26).

Angka pengganda pendapatan tipe I tertinggi adalah sektor industri pengolah hasil pertanian (7) sebesar 3,717, artinya setiap peningkatan permintaan akhir sektor ini sebesar Rp. 1.000,- akan meningkatkan pendapatan total masyarakat Banyuwangi sebesar Rp. 3.717,- Angka pengganda pendapatan tipe II dengan nilai rata-rata sebesar 12,527, artinya kenaikan permintaan akhir rata-rata keseluruhan sektor yang ada sebesar Rp. 1.000,-akan mampu menciptakan pendapatan rata-rata masyarakat sebesar Rp.12.527,-. Sektor industri kerajinan, bahan galian, bahan bangunan (12) dengan koefisien pengganda tipe II tertinggi yaitu sebesar 132,543, artinya kenaikan permintaan akhir sektor ini sebesar Rp.1.000,- akan mengakibatkan peningkatan pendapatan rumah tangga yang bekerja di sektor ini sebesar Rp. 132.543,-.

Lebih jauh gambaran sektor-sektor dengan peringkat pengganda tipe II di atas rata-rata yakni; sektor industri kerajinan bahan galian, bahan bangunan (12), industri lainnya (13), perikanan (5), travel biro (24), angkutan darat (20), komunikasi, pos dan giro (26), pertanian (1). Sebaliknya ada satu sektor yang memiliki koefisien pengganda pendapatan tipe I sama dengan 0,000 yaitu bahan bakar minyak (11), dan terdapat enam sektor yang memiliki pengganda pendapatan tipe II sebesar 0,000 yaitu sektor perkebunan (2), peternakan (3), kehutanan (4), bahan bakar minyak (11), persewaan bangunan dan tanah (29) dan jasa perusahaan (30), berarti investasi yang ditanamkan pada sektor-sektor ini belum mampu memacu pendapatan masyarakat yang bekerja pada sektor tersebut. Implikasi temuan di atas yakni dalam perencanaan pembangunan ekonomi daerah Banyuwangi yang bertujuan meningkatkan pendapatan, maka investasi pada sektor-sektor perekonomian sebaiknya diarahkan pada sektor-sektor yang memiliki nilai koefisien pengganda pendapatan tinggi. Jadi semakin banyak sektor-sektor perekonomian Banyuwangi yang memiliki koefisien pengganda pendapatan tinggi, berarti semakin heterogen sumber mata penghidupan masyarakat atau dengan perkataan lain tidak hanya mengantungkan diri pada satu sektor saja. Berkembangnya sektor-sektor perekonomian secara bersama-sama, saling bersinergi atau saling terkait satu dengan lainnya, menyebabkan kehidupan masyarakat semakin berkembang. Bila mencermati angka pengganda pendapatan sektorsektor yang menampung usaha kecil pariwisata atau pengganda pendapatan usaha kecil pada sektor pariwisata $(17,19,22,24,28,32$ dan 33) dari hasil analisis tampak bahwa angka pengganda pendapatan tipe I dan II rata-rata lebih kecil dari angka pengganda rata-rata umum. Walau lebih kecil, tetapi mereka memiliki peran penting dalam menciptakan peningkatan pendapatan sektor-sektor dalam perekonomian daerah Banyuwangi

Angka pengganda pendapatan tipe II usaha kecil rata-rata sebesar 6,269, artinya setiap usaha kecil meningkatkan permintaan akhirnya atau permintaan barang-barang yang langsung dikonsumksi sebesar Rp 1000, akan mampu meningkatkan pendapatan sektor-sektor ekonomi lainnya (karena adanya peningkatan permintaan output sebagai input oleh usaha kecil) sebesar $\mathrm{Rp} 6.269$, ,. Jika proporsi angkanya dibesarkan, maka setiap terjadi peningkatan per- 
mintaan akhir oleh usaha kecil pada sektor pariwisata sebesar Rp 100.000.000,-, maka akan meningkatkan pendapatan sektor-sektor ekonomi secara keseluruhan dalam perekonomian Banyuwangi sebesar 6,289 x Rp 100.000.000,-yaitu Rp 6.289.000.000,-

Pengganda Pendapatan Tipe I dan Tipe II Sektor-Sektor Ekonomi dan Usaha Kecil pada Sektor Pariwisata dalam Perekonomian Banyuwangi Tahun 2010. Jadi, pengeluaran wisatawan di Banyuwangi yang ditangkap oleh usaha-usaha kecil pada sektor pariwisata, dikeluarkan kembali untuk membeli berbagai macam kebutuhan untuk dikonsumsi langsung (permintaan akhir) akan mampu meningkatkan pendapatan sektor-sektor lain sebesar 6,3 kali lipat dari setiap satu-satuan moneter pengeluaran usaha kecil.

\section{SIMPULAN DAN SARAN}

Beberapa hal yang dapat disimpulkan bahwa nilai ekonomi total ekowisata Rp. 367.435.304.427 atau Rp 29.849.487.049 per tahun. Nilai ekonomi total ekowisata memberikan kontribusi sebesar 31,67 persen terhadap rata-rata produk Domestik Regional atas dasar harga yang berlaku di masing-masing kecamatan Banyuwangi. Kontribusi usaha kecil sektor pariwisata dan ekowisata terhadap pendapatan regional Banyuwangi (nilai tambah bruto) adalah sebesar $\mathrm{Rp} 3.749 .054$ juta atau $15,2 \%$ dari total pendapatan regional Banyuwangi (total Nilai Tambah Bruto) Banyuwangi. Koefisien Input Primer (KIP) usaha kecil pariwisata dan ekowisata sebesar 0,613 $(>0,5)$ termasuk efisien, karena mampu menciptakan upah, gaji, surplus usaha dan pajak tidak langsung yang besar, yang berarti pula mampu menjadi mesin penggerak perekonomian daerah Banyuwangi, khususnya aktivitas-aktivitas masyarakat yang terkait langsung dan tidak langsung dengan usaha kecil tersebut. Usaha kecil pada sektor pariwisata sangat berperan dalam menciptakan permintaan akhir atau permintaan barang dan jasa yang langsung dikonsumsi yaitu sebesar Rp 4.030.330 juta atau $19,36 \%$ dari total permintaan akhir perekonomian Banyuwangi, seperti permintaan berbagai produk pertanian dalam arti luas, industri dan jasa-jasa oleh restoran, rumah makan dan warung. Usaha kecil sektor pariwisata dan ekowisata memiliki dampak pengganda output lebih besar dari pada pengganda rata-rata. Ini menunjukkan bahwa usaha-usaha kecil pada sektor pariwisata memiliki kemampuan sebagai pemicu pertumbuhan perekonomian daerah Banyuwangi. Usaha kecil sektor pariwisata memiliki dampak pengganda pendapatan lebih kecil dari pada pengganda rata-rata. Namun demikian, usaha kecil ini mampu menciptakan pendapatan lebih tinggi terhadap sektor-sektor ekonomi lainnya dari setiap satu-satuan meneter yang dikeluarkan untuk memenuhi permintaan akhirnya.

Penelitian di bidang valuasi ekonomi pariwisata khususnya ekowisata dinilai masih sangat kurang, hal ini seiring dengan pernyataan dari Kementerian Pariwisata dan Ekonomi Kreatif bahwa kontribusi terhadap penerimaan negara bukan pajak (PNPB) pada ekowisata dinilai masih kecil, oleh karena bidang kajian terhadap valuasi ekonomi ekowisata dengan model travel cost diharapkan menjadi salah solusi pemerintah dalam mempertimbangkan pembuatan kebijakan pada sektor wisata khususnya wisata alam dengan nuansa edukasi atau yang sering disebut dengan ekowisata serta dampaknya terhadap perekonomian daerah. Pendekatan travel cost sebenarnya tidak hanya dilakukan hanya pada satu jenis tujuan pariwisata tetapi bisa dilakukan pada berbagai destinasi wisata yang ada pada berbagai daerah sehingga akan dapat terlihat secara simultan seberapa besar kontribusi pembangunan pariwisata khususnya ekowisata yang ada di suatu wilayah, hal ini merupakan bidang penelitian yang bisa dilakukan di masa-masa yang akan dan pembuat kebijakan juga akan dapat melakukan pemetaan suatu kawasan yang dinilai memberikan kontribusi yang paling signifikan terhadap perekonomian suatu wilayah.

\section{DAFTAR REFERENSI}

Antara, M. Juli 2008. Dampak Pengganda Usaha Kecil Sektor Pariwisata Terhadap Petumbuhan Perekonomian Bali: Suatu Pendekatan Model Input-Output. Jurnal Sosial Ekonomi Agrikultur dan Agribisnis, 8(2).

Boo, E. 1990. Ecotourism, The Potensials and Pitfalls. Washington DC: World Wildlife Fund.

Brandon, K. 1996. Ecotourism and Conservation: A Review of Key Issues. Washington DC: World Bank.

Cater, E. \& Lowman, G. 1994. Ecotourism: A Sustainable Option? Chichester, UK: John Wiley \& Sons.

Caulkins, P. P., Bishop, R. C. \& Bouwes, N. W. 1986. The Travel Cost Model for Lake Recreation: A Comparison of Two Methods for Incorporating Site Quality and Substitution Effects. American Agricultural Economics Association, 68(1): 291297.

Choy, Low, D. C. \& Heilbronn, K. 1996. Ecotourism: An Annotated Bilbiography. Research Report South Roland Commenwealth Department of Tourism.

Davis, L. S., Johnson, K. N. \& Davis, K. P. 1987. Forest Management. $3^{\text {rd }}$ Ed. New York: McGraw-Hill Publishing. 
Darusman, D. 1993. Nilai Ekonomi Air Untuk Pertanian dan Rumah Tangga: Studi Kasus di Sekitar Taman Nasional Gunung Gede Pangrango. Makalah disampaikan pada Simposium Nasional Permasalahan Air di Indonesia di ITB, 28 - 29 Juli 1993.

Fandeli, C. \& Mukhlison. 2000. Pengusahaan Ekowisata. Yogyakarta: Fakultas Kehutanan Universitas Gajah Mada, Pustaka Pelajar dan Unit Konservasi Sumber Daya Alam DIY.

Goodwin, H. 1996. In Pursuit of Ecotourism. Biodiversity and Conservation, 5(3): 277-291.

Gujarati, D. 1988. Ekonometrika Dasar. Terjemahan. Jakarta: Penerbit Erlangga.

Gunn, C. A. 1994. Tourism Planning: Basic, Concept and Cases. Third Edition. Philadelphia, PA: Taylor \& Francis.

Hughes, G. 1995. The Cultural Construction of Sustainable Tourism. Tourism Management, 16 (1): 49-59.

Jensen, R. C. \& West, G. R. 1986. Input-Output for Practioners: Theory and Applications. Canberra: Australian Goverment Publishing Service.

Kementerian Kebudayaan dan Pariwisata. 2005. Nesparda. Jakarta: Kementerian Kebudayaan dan Pariwisata Republik Indonesia.

Kementerian Kebudayaan dan Pariwisata. 2006. Nesparnas. Jakarta: Pusat Data dan Informasi Kementerian Kebudayaaan dan Pariwisata Republik Indonesia.

Kling, C. L. 1988. The Reliability of Estimates of Environmental Benefit from Recreation Demand Model. American Journal of Agricutural Economics, 70(4): 892-901.

Lindberg, K. 1991. Policies for Maximizing Nature Tourism Ecological and Benefit, Washington, DC: World Resource Institute.
Miller, R. E. \& Blair, P. D. 1985. Input-Output Analysis: Foundation and Extensions. Englewood Cliffs, New Jersey: Prentice-Hall, Inc.

Peraturan Pemerintah No. 18 Tahun 1994. Pengusahaan Pariwisata Alam Di Zona Pemanfaatan Taman Nasional, Taman Hutan Raya dan Taman Wisata Alam.

Polenske, K. R. 1989. Historical and New International Perspective on Input-Output Accounts. In Frontiers of Input-Output Analysis, edited by R. E. Miller, K. R. Polenske, and A. Z. Rose. New York: Oxford University Press.

Riyanto, B. 1997. Dasar-Dasar Pembelajaan Perusahaan. Yogyakarta: BPFE.

Silver, I. 1997. Truth and Travel: Alternative Tourism isn't Always Responsible Tourism. Cultural Survival Quarterly, 16(2): 54-58.

Smith, V. K., Desvousges, W. H. \& Fisher, A. 1986. A Comparison of Direct dan Indirect Methods for Estimating Environmental Benefits. American Journal of Agricutural Economics, 280-290.

Steele, P. 1993. The Economics of Eco-tourism. In Focus, 9: 4-6.

The Ecotourism Society. 1993. Ecotourism Guidelines for Nature Tour Operators. North Bennington, VT: Ecotourism Society.

Undang-Undang No. 5 Tahun 1990. Konsevasi Sumber Daya Alam dan Hayati dan Ekosistemnya. Jakarta: Departemen Kehutanan Republik Indonesia.

Wheat, S. 1994. Taming Tourism. Geographical, 116: 16-19.

Whelan, T. 1991. Nature Tourism. Washington DC: Island Press.

Ziffer, K. 1989. Ecotourism: The Uneasy Alliance. Working Paper No. 1 Conservation International, Washington DC. 